\section{Clinical evidence guidelines in systemic lupus erythematosus: revaluation}

The paper on the First Latin American clinical practice guidelines for the treatment of systemic lupus erythematosus (SLE) points to some conclusions that need to be further clarified since the bulk of evidence points to a different direction. ${ }^{1}$ Belimumab safety and efficacy has been well documented since its approval during the last 5 years, and in particular the skin and joint domains appear to have a preferential site of major clinical improvement associated with reduction of flares and steroid tapering. ${ }^{2}$ However, the authors when placing the best available evidence of therapy for those domains group belimumab with methotrexate and leflunomide for joint manifestations and indicates superiority favouring methotrexate. For the mucocutaneous manifestations, belimumab is grouped with methotrexate, azathioprine, mycophenolate, cyclosporine and cyclophosphamide, and due to cost and availability, recommendation favours methotrexate and azathioprine.

We feel that this degree of recommendation fails to overview the best medical literature published in the past few years pointing to the superiority of belimumab in improving joint and skin disease when compared with other domains, allowing maintenance of steroid sparing and decrease of adverse events by continuous use of daily steroids also reducing the use of immunosuppressive drugs. ${ }^{34}$ The authors should explain how that conclusion could be reached even when cost issues are raised since there is well-published literature pointing to benefits of belimumab in the long run for several social services when compared with cheaper immunosuppressive drugs that do not reduce steroid intake and lead to increased adverse events and opportunistic infections. ${ }^{5}$ The upcoming opportunity to use the subcutaneous route of administration will certainly create additional opportunities for patients with SLE with active disease that could benefit from add-on existing therapies ${ }^{6}$ The recent questioning of expert consensus on expert consensus addresses this approach properly and indicates that, although nice, it is not necessarily relevant to accuracy. ${ }^{7}$

\section{Morton Scheinberg}

Department of Rheumatology, Hospital Israelita Albert Einstein, Sao Paulo, Brazil

Correspondence to Professor Morton Scheinberg, Department of Rheumatology, Hospital lisraelita Albert Einstein, Sao Paulo 05652000, Brazil; morton@osite.com.br
Handling editor Josef S Smolen

Competing interests None declared.

Patient consent Not required.

Provenance and peer review Not commissioned; internally peer reviewed.

(c) Author(s) (or their employer(s)) 2019. No commercial re-use. See rights and permissions. Published by BMJ.

\section{Check for updates}

To cite Scheinberg M. Ann Rheum Dis 2019;78:e119.

Received 29 August 2018

Accepted 1 September 2018

Published Online First 25 September 2018

\section{GLinked}

- http://dx.doi.org/10.1136/annrheumdis-2018-214385

Ann Rheum Dis 2019;78:e119. doi:10.1136/annrheumdis-2018-214357

\section{REFERENCES}

1 Pons-Estel BA, Bonfa E, Soriano ER. First Latin American clinical practice guidelines for the treatment of systemic lupus erythematosus: latin American group for the study of lup us (GLADEL, Grupo Latino Americano de Estudio del Lupus)-PanAmerican League of Associations of Rheumatology (PANLAR). Ann Rheum Dis 2018:213512

2 Marcondes F, Scheinberg M. Belimumab in the treatment of systemic lupus erythematous: an evidence based review of its place in therapy. Autoimmun Rev 2018;17:103-7.

3 Fanouriakis A, Adamichou C, Koutsoviti S, et al. Low disease activity-irrespective of serologic status at baseline-associated with reduction of corticosteroid dose and number of flares in patients with systemic lupus erythematosus treated with belimumab: a real-life observational study. Semin Arthritis Rheum 2018;0172:30803-X

4 Furie RA, Wallace DJ, Aranow C, et al. Long-term safety and efficacy of belimumab in patients with systemic lupus erythematosus: a continuation of a seventy-six-week phase III parent study in the United States. Arthritis Rheumatol 2018;70:868-77.

5 Díaz-Cerezo S, García-Aparicio ÁM, Parrondo J, et al. [Cost-effectiveness analysis of belimumab in patients with systemic lupus erythematosus in Spain]. Farm Hosp 2015:39:161-70.

6 Doria A, Stohl W, Schwarting A, et al. Efficacy and safety of subcutaneous belimumab in anti-double-stranded DNA-positive, hypocomplementemic patients with systemic lupus erythematosus. Arthritis Rheumatol 2018;70:1256-64.

7 Barosi G, Gale RP. Is there expert consensus on expert consensus? Bone Marrow Transplant 2018;53:1055-60. 